\title{
The Politics of Recession
}


Also by R. W. Johnson

African Perspectives (co-editor)

How Long Will South Africa Survive?

The Long March of the French Left 


\title{
The Politics of Recession
}

\author{
R. W. Johnson
}

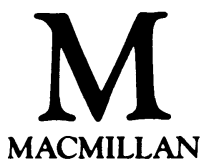


(C) R. W. Johnson 1985

All rights reserved. No part of this publication may be reproduced or transmitted, in any form or by any means, without permission

First published 1985 by

Higher and Further Education Division

MACMILLAN PUBLISHERS LTD

London and Basingstoke

Companies and representatives

throughout the world

British Library Cataloguing in Publication Data

Johnson, R. W.

The politics of recession.

1. Great Britain-Politics and government1964-1979

2. Great Britain-Politics and government1979-

I. Title

941.085'8 DA589.7

ISBN 978-0-333-36787-2

ISBN 978-1-349-17722-6 (eBook)

DOI 10.1007/978-1-349-17722-6

To Anne, Annette and Joan 


\section{Contents}

Preface vii

Part One The New World Order 1

1. The Oil Crisis Revisited 3

2. Far from Vietnam 8

3. Dear Peter ... 13

4. The Politics of Gold 18

5. The New Cold War 23

6. The Way the World has Split 28

7. The End of the American Era 34

8. The Buck Must Go On 39

9. Japanese Take-away 44

10. Mitterrand Ousts a Monarch 50

11. The Pursuit of Sound Money 56

12. The Great Debt Explosion 62

13. Oil, Credit and Crisis 67

14. The Holy Multinational 73

15. How Russians See It $\quad 79$

16. Nuclear Doublethink 84

17. Towards an Independent Europe? 90

Part Two Britain: The Eye of the Storm 105

1. Enoch and Edward 107

2. Tom Nairn and the Break-up of Britain 117

3. Prophets of Doom 123

4. A Prodigal Period 128

5. Generation Game 133

6. Political Posturing 139 


\section{vi Contents}

7. London Rules OK?

8. Let the Bland Lead the Bland 151

9. The Selling of the EEC 157

10. Some British Might-Have-Beens 163

11. What's Good for the Midland ... 169

12. The Way Elections Work Now 174

13. How Soft at the Centre? 179

14. Ireland and the Runcible Men 184

15. The Age of Powell and Benn 190

16. My Country Right or Left? 196

17. Not Cricket, Old Chap 201

18. Our Shirley in Exile 206

19. Cambridge in Command 212

20. Marx's Ghosts 218

21. Pomp and Circumstance 224

22. Must Labour Lose? 256 


\section{Preface}

When I was growing up people always referred to the times through which we were living as 'the post-war period'. After many years of this I became discontented: when would a new period start? Didn't history ever change and move on? We know the answer to this now. The post-war period ended in 1973 and a new era began. Clearly, I should not have been so impatient. For all the difficulties of those times the period from 1945 to 1973 is likely to be remembered as something of a golden age: no world wars, sweeping emancipation from colonial rule, growing detente between East and West, continuous and headlong economic growth. The period which began in 1973 looks altogether less hopeful and at worst it looks positively frightening.

Everything I have written in the last decade has been influenced, in one way or another, by the belief that the most urgent intellectual task before us today is to understand and analyse this new, post-1973 world. To be sure, history will never be an irrelevance. But the situation is quite new. Very little that we learnt about the world of 1945-73 has prepared us for an era of world recession, high inflation, mass unemployment, the chaos over currency and gold which has followed the collapse of Bretton Woods, the growing divide between Europe and the USA, the resurgence of the Cold War, the oil crisis, the world debt crisis and the rise of new economic powers in the world. Every one of these phenomena-and many more besides - first emerged in 1973. The politics of the new period are different too. In place of the the comfortable and optimistic world of social democratic liberalism a new, sharp-edged conservatism is much in evidence. Moreover, change and oscillation have hardly subsided. Even if - as seems likely - the present recession continues for another decade or more, there is no sign of equilibrium at this new level. 
It is already clear that almost everything hangs on the question of how long and how deep the present recession will be. All of the new problems mentioned above would be made more tolerable by a true recovery from recession and some might disappear altogether. The trouble is that in the past the world has only got itself out of a trough like this by means of war. Rationally and humanely such a solution would seem to be precluded this time and already, it is true, we have weathered a number of crises in the post-1973 period which in earlier times would almost certainly have led to war. None the less, the tightening of international tension is evident on every side and there is no certainty that rationality and humanity will continue, even in their present, limited way, to prevail. On the other hand, if prevail they do, the present recession may have no end in sight at all. We are stuck with this frightening and unstable equilibrium. Our only, minimal hope of security lies in at least understanding this new world in which we live. If we fail in that then even hope dies, after which it will not be long before a lot of other things die too.

In selecting essays for this book it was thus not difficult to decide that those dealing with the international political economy should come first. Part Two, which follows, deals solely with British themes. There is, I hope, a more than parochially British rationale to this. For in thinking about the politics of recession Britain occupies a special position. It was the world's first industrial nation and now again it seems to be leading the way: if one wants to see the face of the future it may well be that it is to Britain that one should look. In no other developed economy has the post-1973 recession bitten so deeply. Nowhere else have production and investment fallen by so much and for so long. Nowhere else has unemployment (if honestly counted) risen so far and stayed so high. And nowhere else has the process of de-industrialisation gone so far or the disparity between industrial decline and the booming high-tech financial services sector been so extreme.

In large part Britain's failings now are the result of past success. Her early industrial strength, the enormous benefits of Empire and her freedom from dislocation by war or revolution all helped create uniquely powerful relations of social domination. The British bourgeoisie fused with the older ruling class and thus took over many of its attitudes and prerogatives while the British working class - the world's oldest - learnt to internalise its own subordination. Thus while the British class structure is statistically similar enough to that 
found in other developed capitalist states, it still has a unique rigidity of manner and attitude, the ossified clarity of an ideal type.

This fact permeates every aspect of British society. Where else - to take but one example - could one expect to find a whole house of the national legislature which is a mixture of the hereditary and the appointive, with no democratic element at all? Nowhere else have the democratic and egalitarian impulses of the capitalist free market been so stifled in their social and political expression. Undoubtedly this has been a major cause - perhaps the major cause - of British decline. The sanctity of every form of vested interest in Britain - trade union as well as bourgeois - has produced a classic form of immobilism which has robbed the country of the flexibility needed to face up to its post-imperial challenges, even, it sometimes seems, to face up to its problems honestly at all.

This immobilism, as in Italy or Fourth Republican France, has as its counterpart a government which, despite outward appearances, is woefully weak. At least since 1951 no British government has been bold enough to confront this problem of ossified privilege head on, to complete the democratic revolution in Britain. The result has been a lasting political paralysis. Governments of differing stripes have come and gone, sometimes making quite sweeping attempts at economic reform. They have never persisted for long and the failure to attack the class root of the problem has reduced these reforms to fore-doomed ripples on the surface. This in turn has meant that Britain's decline, despite the appearance of frenzied effort to halt it, has been pretty much a matter of free fall.

This almost idealised form of class society entered the recession, typically enough, locked in a social struggle of surpassing intensity the miners' strike of 1973-4. This was followed by 'business as usual' - that is to say, five more years of weak, temporising government. These Labour years stood for nothing so much as the exhaustion of the spirit of reform. The 1945-51 Labour government, despite many lost opportunities, had carried through a major reform package. The 1964-70 government had at least begun with reforming intentions. The 1974-79 Labour government had clearly given up the ghost almost from the start. Its ambition was just to survive, treading water in the Micawberish hope that an international recovery would somehow 'turn up'. It didn't, of course.

This was followed by the Conservative counter-revolution of Thatcherism - which, again, has an important international dimension. 


\section{x Preface}

Nowhere else has there been a government more consistently and tough-mindedly intent on reducing inflation through the age-old remedy of the balanced budget and regardless of the human cost. And nowhere else among the Western democracies has such a government had such a free hand-the time, the legislative majority, the undivided executive authority - to work its will. J. K. Galbraith was only one of many foreign observers to grasp that Thatcherism would provide a virtual laboratory test of monetarist doctrine.

Such a government held a certain promise. It was bold, it was strong, and it was utterly committed to free market capitalism. Logically this ought to have led it to attack at least the grosser feudal anachronisms in British society. Instead it was soon clear that the government was concerned only to defer to and even to reinforce such institutions. At the end of the Thatcher experiment it seems certain that the pro-modern and anti-democratic encrustations on British society will have been measurably strengthened, not weakened.

On both counts then - Britain as the paradigm class society and Britain as the eye of the storm in the world recession - it seems clear that the 'model' the country poses to the world will become even more extreme. On the one hand, Britain's relative economic decline, merely relative until 1979, has since then become absolute: by 1983 industrial production was below not only the 1979 level but even the 1970 level. No other developed country has known anything like this. On the other hand, at least as fast as government policy has shrunk the size of the overall cake it has also redistributed what remains quite sharply away from the have-nots towards the haves. This remarkable - and hideous - process again makes Britain a virtual laboratory test case of retrogressive social change in the world of recession. No one can live through this in Britain without recalling the old Chinese saying 'may you live in interesting times' - or remembering that this saying was a curse.

The essays in this book were all written for an audience which is, I hope, both popular and serious. Anyone who tries to write about politics in this vein is bound to be conscious of the giant shadow cast by Orwell. On the one hand, Orwell was determined to avoid the triviality of the popular press and the clubby, collusive atmosphere of 'the posh papers'. 'What I have most wanted to do throughout the past ten years', he wrote in Why I Write, 'is to make political writing into an art.' On the other hand, the cautious, neutered tone of the academic journals was not for him: 'my starting point', he wrote, 'is 
always a feeling of partisanship, a sense of injustice'. He wrote, moreover, with a wonderful directness and in a beautifully plain English - the key to getting across serious subjects to a wide audience - which makes him seem an accessible model. Appearances are deceptive though: this sort of thing is far harder than he made it look.

I have tried to take all this to heart. A publisher friend once described my essays as 'a sort of reverse Dale Carnegie: how to influence people by losing friends'. I can't say about influencing people, but I have tried to be direct. This is not always easy in Britain where public debate is hemmed in not only by legislative restriction, but by the high premium placed on not causing undue upset or embarrassment. It says a great deal for Paul Barker, the editor of New Society (where a number of the essays in this book first appeared), that in his pages I was always able to write what I wanted the way I wanted.

He must often have disagreed with me, but even when I wrote in a way which was likely to be unpopular or which departed quite sharply from the general tenor of his magazine, he raised no demur. Paul deserves my thanks, but he deserves more than that. His creative indulgence - to many others besides myself - has helped maintain an honourable, if often isolated, tradition of real openness and independence. Most, perhaps, of those who write for New Society, are, like myself, liberals or socialists of one stripe or another, but you can find Conservatives and Communists in its pages too. This is a rare and precious thing. Perhaps the best way of expressing Paul's achievement is to ask, were Orwell still writing today, who would publish him? Not Tribune any more, alas. If one runs through the list of possibilities one realises fairly soon that only New Society would allow him the space, independence and catholicity he required. I can think of no higher accolade for Paul than that.

My opinions are my own, but I do have other debts to acknowledge all the same. I am grateful to Steven Kennedy at Macmillan for his persistence in getting me to do this book, and I am also grateful to two of my Magdalen colleagues, Frank Parkin and Andreas Boltho, who have both influenced me more than they probably realise. Frank's intellectual influence was particularly important to the long essay on the Conservatives, while Andreas has frequently made me re-examine my views about international economic questions. During three of the years when many of my New Society articles were written I was 


\section{xii Preface}

also Senior Bursar of Magdalen and I should, too, note my gratitude to the Bursary staff, particularly Joan Forrest and Annette Richardson, for putting up with my Bohemian ways, which provided the only way of doing that job and meeting my deadlines. Finally, and most of all, I owe a further debt to Anne Summers, always my first and toughest critic even though she was usually heavily involved with writing of her own.

December 1983

R. W. JOHNSON 